SERVING

\title{
A NEW \\ NATION
}


The Institute of Southeast Asian Studies (ISEAS) was established as an autonomous organization in 1968. It is a regional research centre dedicated to the study of socio-political, security and economic trends and developments in Southeast Asia and its wider geostrategic and economic environment. The Institute's research programmes are the Regional Economic Studies (RES, including ASEAN and APEC), Regional Strategic and Political Studies (RSPS), and Regional Social and Cultural Studies (RSCS).

ISEAS Publishing, an established academic press, has issued more than 2,000 books and journals. It is the largest scholarly publisher of research about Southeast Asia from within the region. ISEAS Publishing works with many other academic and trade publishers and distributors to disseminate important research and analyses from and about Southeast Asia to the rest of the world. 


\section{SERVING \\ A NEW \\ NATION \\ Baey Lian Peck's Singapore Story}

\section{Ooi Kee Beng}

\section{누바노}

INSTITUTE OF SOUTHEAST ASIAN STUDIES 
First published in Singapore in 2011 by

ISEAS Publishing

Institute of Southeast Asian Studies

30 Heng Mui Keng Terrace

Pasir Panjang

Singapore 119614

E-mail: publish@iseas.edu.sg

Website: বhttp://bookshop.iseas.edu.sg>

All rights reserved. No part of this publication may be reproduced, stored in a retrieval system, or transmitted in any form or by any means, electronic, mechanical, photocopying, recording or otherwise, without the prior permission of the Institute of Southeast Asian Studies.

\section{(C) 2011 Baey Lian Peck}

The responsibility for facts and opinions in this publication rests exclusively with the author and his interpretations do not necessarily reflect the views or the policy of the publisher or its supporters.

\section{ISEAS Library Cataloguing-in-Publication Data}

Ooi, Kee Beng, 1955-

Serving a new nation : Baey Lian Peck's Singapore story.

1. Baey, Lian Peck.

2. Businessmen-Singapore-Biography.

3. Singapore-Officials and employees-Biography.

I. Title.

DS610.73 B13O61

2011

ISBN 978-981-4345-42-2 (hard cover)

ISBN 978-981-4345-43-9 (e-book, PDF)

Cover design by Chris Lim Kah Wai

Cover photos of Dr and Mrs Baey Lian Peck by Ooi Kee Beng

Typeset by Superskill Graphics Pte Ltd

Printed in Singapore by Mainland Press Pte Ltd 